TEME, г. XLV, бр. 1, јануар - март 2021, стр. 33-42

Прегледни рад https://doi.org/10.22190/TEME200112003S

Примљено: 12. 1. 2020.

UDK 811.111'25

Ревидирана верзија: 6. 2. 2021

Одобрено за штампу: 26. 2. 2021.

\title{
RELEVANCE OF TRANSLATION IN ESP TEACHING METHODOLOGY
}

\author{
Nadežda Stojković \\ University of Niš, Faculty of Electronic Engineering, Niš, Serbia
}

\begin{abstract}
This paper offers an observation and discussion on the relevance and scope of presence of translation within English for Specific Purposes courses in academic settings of the Faculty of Electronic Engineering and Faculty of Medicine, University of Niš. There is concern with methodological issues of translation skills regarding domain terminology. This subsumes translation methodology, finding precise target language equivalents, as well as determining whether to translate a text, respecting the syntax of the target language, or to paraphrase it with the primary aim to most precisely convey information contained in the original. The main argument and the issue of the survey conducted with the students of both faculties is direct correlation between translation, or absence of it for that matter, and the cognition of the domain content taught. Then, there is an emphasis on a wider social context that implies inducing in students the awareness of the responsibility they as future professionals and experts in their field have towards their own mother tongue in the dissemination of content knowledge. It is common in the Serbian scientific and professional environment that the translation of scientific texts in English is done by domain experts without consulting linguists, philologists of Serbian language. The consequence is mere (and often incorrect) transliteration of English scientific terminology, and ultimately uncurbed influx of foreign terminology. Yet another argument on the relevance of the previous one is that translation enhances soft transversal skills such as thoughtfulness and critical thinking which among others benefit comprehension of the domain knowledge, as it has been noted that professors, and then students use the English terminology while speaking Serbian, where the latter group do not fully understand the content presented in such scientific 'newspeak'. The paper presents concrete teaching practice which has for its goal inducing the students with cautiousness when choosing professional terminology in either language.
\end{abstract}

Key words: translation, paraphrasing, equivalents, transliteration, social responsibility.

\footnotetext{
* Аутор за кореспонденцију: Надежда Стојковић, Електронски факултет у Нишу, Александра Медведева 14, 18000 Ниш, Србија, nadezda.stojkovic@elfak.ni.ac.rs
} 


\title{
ЗНАЧАЈ ПРЕВОЪЕЊА У МЕТОДИЦИ НАСТАВЕ СТРУЧНОГ ЕНГЛЕСКОГ ЈЕЗИКА
}

\author{
Апстракт
}

У овом раду разматрају се важност и заступљеност превода у настави стручног енглеског језика на Електронском и Медицинском факултету Универзитета у Нишу. Прво се разматрају методичка питања везана за развој вештине превођења стручне терминологије, налажење прецизног еквивалента, као и одлучивање да ли да се текст преведе поштујући синтаксу оригинала или да се парафразира са основним циљем да се најпрецизније пренесу информације садржане у оригиналном тексту. Затим се анализира шири друштвени контекст. Инсистира се на томе да је важно студентима усадити свест о њиховој сопственој одговорности као будућих професионалаца и експерата према употреби матерњег језика при дисеминацији научних садржаја. У нашем научном и професионалном окружењу превод научних текстова са енглеског језика често раде сами научници без консултовања филолога за српски језик. Последица тога је једноставна транслитерација научне терминологије преузете из енглеског језика, те неконтролисани уплив страних речи. Још један аргумент који појачава значај претходно наведеног је да превођење унапређује друштвене и менталне вештине и да доприноси бољем разумевању самог научног садржаја. Примећено је да професори, а затим и студенти користе енглеску терминологију док причају српски, при чему студенти не показују пуно разумевање материје представљене тим научним „новоговором”.

Кључне речи: превођење, парафраза, еквивалент, транслитерација, друштвена одговорност.

\section{TRANSLATION OF SCIENTIFIC CONTENT INTO SERBIAN}

Translation in English for Specific Purposes (ESP) (equally so in Languages for Specific Purposes) is of crucial relevance, grounded in the fundamental rationale of this particular form of English Language Teaching (ELT), that being international expertise dissemination of the practice community. This dissemination is a two-way process, the experts not only conduce their findings on the particular professional/scientific domain in question to the scientific audience worldwide via the medium of English language, but they are also the first recipients of that kind of knowledge coming from other practice communities, and are those able to comprehend the novelties thus transmitted. That being the case, it is most often them, rather than professional translators or linguists in general, who offer an equivalent term in their mother tongue. This way, professionals and/or scientists are knowledge mediators who take upon themselves the role of facilitators in understanding specialized texts and terminology for the scientific and technical audience (Newmark 2006).

The two identifiable reasons why specialized terminology is not translated and why consultancy of trained translators is not sought, is the following. First, the development of science today is undeniably fast, especially in areas of information technologies (IT) and medicine. The 
breakthroughs in those sciences are presented in scientific journals and have immediate dissemination and consequent application in theoretical knowledge and practice. Put in simple terms, there is no time for translation. A concurrent reason is that dealing with science implies utmost necessity for precision which is secured if practicing scientists use the very same terms thus avoiding any possibility of obscurity of meaning or ambiguity. There are areas of practice that must necessarily rely only on English as a medium of communication, and one of the most representative ones is air traffic control, exemplifying those fields where the need for utmost precision in communication is imminent. Yet, those although unquestionable, are not to be considered a justification for not translating throughout various professional and scientific communities, but are rather to be clearly distinguished from fields where translation is possible and beneficial. It is here that the other possible reason for translators not being introduced and actively involved in transferring new and existing scientific knowledge into Serbian can be observed and ascribed to the absence of awareness of the wide relevance of linguistic issues involved.

When professionals, university professors provide the equivalent they most often just use the very English term itself yet pronounced with Serbian sounds. Therefore, there is extensive linguistic borrowing in the form of transliteration. However, often even this transliteration is approximate as depending on the amount of knowledge of the professor who starts using the particular term. One such example is the concept of 'fading' in telecommunications that in Serbian is 'feding'. After numerous doctoral theses proposed for defense at the aforementioned faculty that in their title contain 'feding', the author insisted the colleagues find how it appeared instead of 'fejding'. They traced back the person who introduced the term, who was the first to start dealing with that concept, and found it was a professor who used to pronounce that word as /fedin/ and so transcribed it and initiated its use as such in Serbian.

As the developments both in the fields of electronics and medicine are overwhelmingly numerous and fast, the number of new terms is high. Also, the scientific literature is primarily in English. Even Serbian scientific journals, all such issued by the University of Niš for example, are published in English. Being so much exposed to this language, the professors tend to use English terminology in lectures as well, and to a large extent. The amount to which English terminology pronounced in Serbian is used can be observed with students who when in English classes do English to Serbian translation speak some new kind of Serbian language in which nouns, verbs, even some adjectives and adverbs, though with Serbian inflexions, are actually English words with just auxiliary verbs being Serbian. When a student translates in such way, the author asks for actual Serbian equivalents, or asks for a clarification in Serbian. For instance, when asked for a referent of 'rapidno', 'sekvenca', 
'freim', 'raster', the students far too often do not know, in this way illustrating incomprehension of the content matter even in their mother tongue, which is a serious consequence of such indiscriminate, direct use of foreign words.

\section{METHODOLOGY OF TRANSLATION IN ESP COURSES}

Translation as claimed here to be of high relevance is valid at more advanced levels of ESP instruction where students possess at least intermediate level of English language proficiency. Then, it is considered the fifth, highly important skill (Munday 2001). Since language learners involved are not English language majors and do not possess theoretical linguistic education, they need to be introduced into why translation matters in their field of expertise, and then what kind of translation they need to deal with. This excludes theories and practice of translation as students of language majors are to master. The type of translation that domain specialists are to know and to practice is functional-semantic translation (Nord 1997). Translation in ESP training is relevant for two reasons: 1. it facilitates comprehension of specialized texts (Reiss 1989); 2. students need to be able to relate lexis and structures of target language into their mother tongue equivalents (Nord 1997). Students are to be presented with the relevance of translation and their own social responsibility as regards the spread of the knowledge both to the worldwide and domestic scientific and practice community in the way that allows for its complete comprehension.

When introducing work on translation in class, the author found it useful to first discuss this skill with students, why or if it is needed, and in what form. During such conversations there always, expectedly, arises the undeniable fact that their communities of practice (IT and medicine) are becoming ever more international and therefore do require an imminent bridge language. Next, due to that, students' perception is that technicalscientific text types are exclusively denotative and inexpressive. This is the first point that needs to be unveiled. It quite understandably reflects what in ESP theory is considered a fossilized misapprehension about the nature of scientific discourse, the preconception that there are expressive (usually associated with literature) and technical-scientific texts which are mutually inherently different. Whereas the former would require complex translation to achieve all the nuances of meaning and style, the latter is presumably straightforward and requires precision in one-to-one equivalents (Zheng, 2017).

Students need to be faced with their (future) role as knowledge communicators and knowledge mediators of the social practices they are agents of. Therefore, preceding translation, there is work on domain texts (spoken and written) and their linguistic features (lexical, grammatical, syntactic, morphological, stylistic), that is, getting students to recognize 
discursive features of the relevant discourse community. They are to realize the direct interconnection between linguistic communication and social practices. When commencing work on translation with ESP students, overcoming the preconceived, yet uninformed notions of how translation is to be done is crucial (Nord 1991). Future professionals (of IT and medicine for this matter), unlike students of linguistic majors, are not familiar with the basic premises of translation, that one-to-one correspondence is impossible as formal and semantic differences between two languages are the barriers. Instead of a misconception that there can be only one correct rendition of the source text (insistence on exactness inherent in hard sciences students profiles), they need to reconceptualize their idea of the relation between the source and target text as proper in a functionally apt way (Vermeer 1986, 33), beyond mere transcoding of words and sentences, the approach that is characteristic of instrumental translation (Nord, 2002).

Therefore, students are to distinguish between two kinds of translation needed in scientific and professional settings, precise translation where the carrier of meaning is mainly specialized domain terminology, and translation that is a paraphrase that conveys the exact information of the source text, yet does not need to closely follow its structural flow. They are to internalize the notion of translation as a facilitating means of interlingual functional exchange of information, and that to achieve it, the source and target texts need to have an identical communicative value not regarding the form, but content. This is a knowledge communication approach to translation that is employed where context is the reference point of equivalence.

\section{TRANSLATION AND COGNITION SURVEY}

Significantly long teaching practice within the area of ESP of the author, some twenty years, have provided ample understanding into the essential correlation between the relevance of translation and its very purpose of comprehension of concepts they denote. Namely, our thesis is that translation matters not only in ESP classes, but we dare say even more importantly for students' comprehension of the professional content that is transferred through professional terminology. What started as a far too frequent situation observed in classes was proven a fact in two simultaneously conducted surveys at the Faculty of Electronics and Faculty of Medicine, University of Niš. The author, the ESP lecturer at both faculties, repeatedly asked students to translate the Serbian-English transliterated words into another Serbian word, to provide synonyms, which students would most often fail to do. It was evident first to the lecturer, and then through conversation to the students themselves that this inability has profoundly serious implications. Students would then become aware that they do not understand the content matter of their 
courses. This was a huge discovery for them when faced with the harsh reality of it.

In the academic school year 2018/19 the author conducted a descriptive, open questions survey with the students of both faculties to inquire about their insights as to why the situation is that grim. At the Faculty of Electronic Engineering, the survey was taken by 43 students at year three, and at the Faculty of Medicine, 17 students at year one. The survey had six questions and students were asked to present their opinions on them in short. The survey was conducted at the beginning of the autumn semester, very soon after the beginning of the course.

Survey questions:

1. Is translation of professional and/or scientific terms into Serbian relevant?

2. Why yes/no?

3. Does the use of Serbian terms help or hinder your professional communication?

4. Who/what are your 'models' for using Serbian/English terminology when speaking Serbian?

5. Should there be a standardized way of using English terminology?

6. If yes - who should be responsible for standardizing foreing professional and scientific terminology?

Before proceeding into the insights gained from students' responses, it is illuminating for this argumentation to explain that the author finds these descriptive, free form answers surveys most useful for her own teaching practice, rather than those that require statistical analysis of the results, yet not denigrating the latter in any way. Rather, for the perception and the sentiment of the author, this type of survey yields answers that she can directly use to enhance her teaching practice. Among students' answers there are often extraordinarily wise and creative ideas that truly are indispensable for improving the teaching practice and tailoring it more adequately to students' needs, as well as the actual requirements of the given time and setting.

Thus, in this particular survey the following was found:

1. There were $57 \%$ of students who answered yes, and $43 \%$ said not relevant.

2. Here most revealing answers were mostly of the following kinds:

- It is important because in that way we preserve our mother tongue.

- We need Serbian terminology because we speak in our country, when we are abroad we can speak English. France and Croatia take care of their native tongues. 
- English helps us communicate with everyone in our field, terminology should be in English so that we can freely talk with our colleagues at work here. If we use Serbian words we cannot understand each other fully because we perceive Serbian equivalents differently.

3. There were $54 \%$ students who claimed that translated terminology in Serbian makes them feel confused and said it should not be used because of that. The remaining number of students pointed out that Serbian terminology helps them better understand the subject matter in the domain field only when it is properly translated.

4. This question was answered - according to professors by $84 \%$ of canvassed students. The rest answered vaguely, according to media, internet, journals.

5. Total of $97 \%$ students agreed that terminology should be standardized officially.

6. The answers here were $75 \%$ said that terminology standardization should be done by professors and scientists because they know what it means. There were $19 \%$ of students who said professors of English language, and 6\% said professors of Serbian language.

These conflicting numbers clearly indicate discrepancies in opinions in students themselves. Here it is important to acknowledge that the survey was intentionally conducted at the beginning of the term, before students had enough time to comprehend themselves why and how translation assists their cognition. During the course and numerous situations through which the author intentionally guides students, they learn about the language in its wider context - to include questions of deep understanding, social responsibility and adequacy. The rationale for the survey was to prove to the author the necessity of inducing in students the awareness of using precise, approved Serbian terminology.

The work on understanding relevance of translation in professional discourses implied dealing away with the following widely spread misconceptions: 1 . Anyone who speaks a language can automatically translate anything; 2. Translation is just a word-for-word adaptation of the original, in another language. Instead of these stances, together, through deduction, we would come to the following notions: 1 . Translators are experts in specific fields of scientific language; 2 . Translation is not just about words, but also concepts that lie underneath. The translation and cognition of concepts develop in synchronization. Translation transfer is a complex cross language activity and an integration of various disciplines included in that process. Sometimes, satisfactory translation implies the process of reformulating, rewording, or paraphrasing - also known as intralingual translation, which often is the case in hard sciences and students should be aware how to apply it. 


\section{SOCIETAL IMPLICATIONS}

The rationale for greater inclusion of translation practice in ESP classes in the courses English for IT and English for medicine at the University of Niš is the perceived need for accommodating students with easier and more profound understanding of the content matter, and inducing in them the awareness of societal linguistic consequences of their professional practice. Students of these two particular scientific fields will soon be the first recipients of new forms of those domains advances, and thus the first to disseminate it further. For that, they need to be equipped with directions as to how to use that new incoming terminology (Nord 1997).

Through discussing with students their perceptions of the professional terminology as mostly now used, merely transliterated into Serbian, they come to their own conclusions as to how that impacts (their own) comprehension of the matter, and at the same time, what happens to our mother tongue, if that large influx of new words, and in such a form, is justifiable. This kind of work on translation issues in professional domain language bears one more significance. Students know full well they need English language for mastery in their careers. Yet, with this practice, they start to perceive language as not just a taken for granted tool, but a field of rational comprehension and expression in which they are not passive recipients, but active in their responsibility towards it due to their professional expertise and their awareness of the role of languages, both English and Serbian.

The work on that awareness was carried out throughout the semester in the form of discussions with students, as open questions that implied the application of deductive logical thinking. The author, in her teaching methodology firmly believes that deduction is the most beneficial format of inducing knowledge in students. Thus, there were occasional discussions, when it was appropriate and associative with the unit that was done in class, regarding each of the issues raised in the survey.

The students of both faculties deal with hard sciences and it is rightful to assume they are not closely informed with the issues of language standardization and its relevance. Then, it must also be acknowledged that there is a highly sensitive situation in Serbian language regarding actual standardization of contemporary scientific terminology. As remarked in the Introduction, we are at present witnessing lack of cooperation, or rather lack of even an incentive for cooperation, between Serbian linguists, English language professionals and domain science experts. To our understanding, this leaves domain experts 'on their own' when it comes to the question of which form of the word to use, the original yet transliterated, or some Serbian equivalent. Here we say 'some' precisely because there is no standard instruction on finding most suitable translation and even more importantly, no channel of entering that translation into a uniform use 
throughout the country. Such a situation reflects heavily on students' use of foreign terminology, and explains the contradictory result numbers of the survey.

The aim of the discussions in class are intended to introduce students with the notion that a truly educated professional, a wellrounded, mature person, needs to be actively aware of the language they choose to use. Students exhibit high interest in these discussions and are eager to grasp the relevance of very questions set since they know that English is the language of their sciences, respectively. Through those talks in which they all participate freely with stating and defending their opinions on each of the questions from the survey, they begin to learn, first of all, the very relevance of raising those questions, which for the author is the ultimate goal. We are of the opinion that these broad issues that implicate various stakeholders in the society cannot be remedied easily, as an intricate societal consensus is needed. What we find a real, feasible contribution to that social dialogue, is making future professionals aware how to use their professional language carefully. It will be up to them to consider whether to use foreign words in their mother tongue, or use the existing corresponding words which satisfy all the relevant nuances of meaning of the domain term in question, or to consult Serbian language professional linguists for advice. This can be a step forward in educating engineers and medical doctors towards them having broader vistas of the overall societal impact of their work.

Finally, we need to stress out emphatically once again that this is an example from teaching practice in which a specific issue was observed as repeatedly hindering cognition on the part of the student and being closely related to the unsolved situation with translation standards of English professional terminology in Serbia. The attempted, and we are free to say, achieved goal of the author was to make students aware to carefully choose the term in either language, to check if they themselves fully comprehend the concept it designates and to feel responsible for both their mother tongue and the advancement of their professional community.

\section{REFERENCES}

Munday (2001) Introducing Translation Studies: Theories and Application. London: Routledge.

Newmark (2006) About Translation. Beijing: Foreign Language Teaching and Research Press.

Nord (1991) Text Analysis in Translation: Theory, Methodology and Didactic Application of a Model for Translation-Oriented Text Analysis. Amsterdam: Rodopi.

Nord (1997) Translating as a Purposeful Activity-Functional Approaches Explained. Shanghai: Shanghai Foreign Language Education Press.

Nord (1997) A Functional Typology of Translation. Amsterdam: Rodopi.

Nord (2002) Manipulation and loyalty in functional translation, Text and Reception in Southern Africa Journal, 14(2), 32-44. 
Reiss (1989) 'Text types, translation types and translation assessment". In: Chesterman, A. (ed.). Readings in Translation Theory.

Vermeer (1989) Skopos and Translation Commission. Heidelberg: Universitat.

Zheng (2017) Introduction to Functionalism and Functional Translation Theory. Advances in Social Science, Education and Humanities Research, 185, 623-627.

\title{
ЗНАЧАЈ ПРЕВОБЕЊА У МЕТОДИЦИ НАСТАВЕ СТРУЧНОГ ЕНГЛЕСКОГ ЈЕЗИКА
}

\author{
Надежда Стојковић \\ Универзитет у Нишу, Електронски факултет, Ниш, Република Србија
}

\section{Резиме}

У овом раду разматрају се важност и заступљеност превода у настави стручног енглеског језика на Електронском и Медицинском факултету Универзитета у Нишу. Прво се разматрају методичка питања везана за развој вештине превођења стручне терминологије, налажење прецизног еквивалента, као и одлучивање да ли да се текст преведе поштујући синтаксу оригинала или да се парафразира, са основним циљем да се најпрецизније пренесу информације садржане у оригиналном тексту. Затим се анализира шири друштвени контекст. Инсистира се на томе да је важно студентима усадити свест о њиховој сопственој одговорности као будућих професионалаца и експерата према употреби матерњег језика при дисеминацији научних садржаја. У нашем научном и професионалном окружењу превод научних текстова са енглеског језика често раде сами научници без консултовања филолога за српски језик. Последица тога је једноставна транслитерација научне терминологије преузете из енглеског језика, те неконтролисани уплив страних речи. Још један аргумент који појачава значај претходно наведеног је да превођење унапређује друштвене и менталне вештине и да доприноси бољем разумевању самог научног садржаја. Примећено је да професори, а затим и студенти користе енглеску терминологију док причају српски, при чему студенти не показују пуно разумевање материје представљене тим научним „новоговором”. 